\title{
Hiljaisen tuen teot?
}

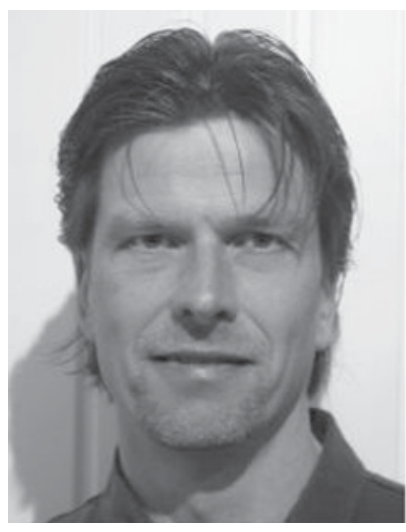

Suuri osa tämän teemanumeron artikkeleista ja katsauksista käsiteltiin ja hyväksyttiin lehtemme toimituskunnan kokouksessa maanantaina 22 syyskuuta. Pitkän työlistan viimeisenä kohtana oli Anu Tenhusen meille lähettämä artikkelikäsikirjoitus otsikolla "Hiljaisen tuen tekoja - kertomuksia luokanopettajien keinoista mahdollistaa ryhmään kuulumista". Kiinnitimme huomiomme artikkelikäsikirjoituksen yleisten lähtökohtien laajempaan yhteiskunnalliseen merkitykseen. Pohdimme kuitenkin, oliko sen tulokulma alati tärkeisiin syrjäytymisen ja ulosjoutumisen teemoihin aikuiskasvatustieteen näkökulmasta liian koulu-, opettaja- ja opetuskeskeinen. Totean häpeillen "esiintyneeni” yhteiskuntatieteellisesti suuntautuneen aikuiskasvatuksen itsetietoisena reviirinvartijana.

Vajaa vuorokausi kokouksen päättymisen jälkeen Jokelan koulusurmat toistuivat Kauhajoella. Yhdentoista suomalaisnuoren elämä päättyi traagisesti kouluympäristössä. Surmatyön tekijä Matti Juhani Saari ei kuitenkaan median kuvausten perusteella ollut yksinäinen tai syrjäytynyt, kauhuelokuvien kuvastosta esiinmarssinut erakoitunut ihmishirviö. Hän oli nuori aikuinen, suomalainen ja pohjalainen mies, koulutoverien ja opettajien kuvausten perusteella tavallinen tyyppi ja keskinkertainen oppilas. Hän kuitenkin päätyi surmaamaan koulutoverinsa ja itsensä laillisesti hallussa pitämällään käsituliaseella. Ehkä juuri tästä syystä meidän on ollut kovin vaikea selittää hänen tekoaan. Olisiko hänen "tavallisuutensa" myös syy siihen, että Kauhajoen tapahtumat katosivat mediasta yllättävän nopeasti? Oman mielenrauhamme säilyttämiseksi meidän on ollut turvallisempi pohtia Idols-tuomareiden ihmissuhdepelejä kuin pakottaa itsemme kohtaamaan Kauhajoen ahdistavat tapahtumat.

Ikävä kyllä kaunis ja lämmin syksy on ollut henkirikosten suhteen harvinaisen synkkä. Perheväkivalta vaikuttaa saavuttaneen äärimmäisen muotonsa. Yhteistä surmateoille on ollut se, että ne on tehty arkielämän lähipiirissä, koulussa ja kodeissa. Uhrit ovat olleet surmien tekijöiden lähimmäisiä; perheenjäseniä, lapsia ja koulutovereita. On erittäin harvinaista, että vanhemmat surmaavat omat lapsensa. Yleinen pahoinvointi purkautuu sisäänpäin. Asiantuntijat ovat kuitenkin huomauttaneet, että tilastollisesti vuosi 2008 tai tämä syksy ei tilastollisesti poikkea aiemmista.

äätöksentekijöiden reaktiot Kauhajoen tragedian jälkeen ovat olleet lähes ultrarationaalisia. Niissä on paneuduttu lähes yksinomaan, Anu Tenhusen sanoin, uhkien tunnistamiseen ja torjumiseen. Aselain kiristämisessä toimenpiteet näyttävät kuitenkin jäävän pahasti puolitiehen. En saata ymmärtää miksi. Anu Tenhunen toteaa pelkkiin uhkiin keskittymisen kaventavan näkökulmaa, jättäen niin yksilöiden kuin yhteisöjen toimintamahdollisuudet pimentoon. Hän toteaa myös: "Tilastollisesti uhkaa torjuttaessa ihmisyydelle jää sivurooli."

Ehkä ongelma onkin yksiselitteinen seuraus yhteiskunnan vajavuudesta ja kyvyttömyydestä luoda vahva perusta inhimilliselle (yhteen)kuulumisen tunteelle? Yhteisöllisyyden koossa pitävä voima on ehtynyt, myös kouluissa. Mutta 
voiko yhteisöllisyyttä enää elvyttää, jos se on jo aikoja sitten menettänyt elinvoimansa? Alettiinko sosiaalista pääomaa tutkia ja sen merkitystä pohtia vasta, kun se oli menettänyt arvonsa? Merkitsisikö henkilökohtaisista opetussuunnitelmista ja luokattomista lukioista luopuminen paluuta menneisyyteen?

Syitä ja taustoja koulusurmille on etsitty myös uudesta mediasta, YouTubesta, MySpacesta sekä irc-gallerioista. Ylirationaalisuudesta ja sen aiheuttamasta tunnelinäöstä on mielestäni oiva esimerkki se, että vanha media, esimerkiksi televisio ja sen nykyinen ohjelmatarjonta näyttävät unohtuneen meiltä lähes tyystin. Etenkin kaupallisten televisiokanavien parhaaseen primetimeaikaan lähetetään lähes joka arki-ilta toinen toistaan raaempia rikos- ja väkivaltasarjoja. Ensin mainittujen ”pääosissa” ovat tätä nykyä lähes poikkeuksetta sarjamurhaajat.

Jonkinasteisen yhteiskunnallisen skitsofrenian tai kaksinaismoralismin ääripää saavutettiin mielestäni (taas kerran) keskiviikkona 12.11.2008. MTV3:lla lähetettiin kello 20.00 alkaen ajankohtaisohjelma "45 minuuttia”. Sen aiheena oli lasten ja nuorten pahoinvointi, jota tarkasteltiin lähinnä päivähoidon, koulun ja nuorisotyön kontekstissa. Kyseisen ajankohtaisohjelman jälkeen samalla kanavalla alkoi amerikkalaisen rikossarja C.S.I:n uudet jaksot. En kyseistä sarjaa seuraa. Ohjelmatiedoissa tuon illan jakso kuvattiin kuitenkin seuraavasti ”Kuollut nukke. Löytääkö C.S.I Saran ennen miniatyyrimurhaajan lopullista iskua?” Viikkoa aiemmin C.S.I:n uusintajaksoa edelsi samaisessa ajankohtaisohjelmassa esitetty Pekka-Eric Auvisen vanhempien haastattelu.

$\mathrm{K}_{\text {our }}$ ulut ja opettajat asetetaan kerta kerran, myös Kauhajoen ja Jokelan tapahtumien jälkeen, yhä enemmän vartijoiksi. Opettajien ja muiden kasvatusalan asiantuntijoiden oletetaan (tai toivotaan) kykenevän yleisen pahoinvoinnin lievittämiseen. Yhteiskunnan taholta hyvinvointitalkoisiin osallistutaan koulutusinfrastruktuurin kehittämällä. Pieniä lähikouluja lakkautetaan ja asutuskeskuksiin perustetaan yhä suurempia koulutusyksiköitä. Suomi on ehkä liian kauan ollut pienten, alle viidenkymmenen oppilaan koulujen luvattu maa. Koulujen sisäisiä toimintoja kilpailutetaan ja ulkoistetaan laadun kustannuksella. Vaikka koulujen ymmärretään olevan osa yhteiskuntaa ja yhteiskunnan tilan heijastuvan koulun arkeen, oletetaan opettajien luokkahuoneissaan kykenevän suvereenisti hallitsemaan niin reaali- kuin virtuaalimaailman entistä paradoksaalisemmat haasteet.

Opettajien työnkuva on laajentunut. Heidän on olisi kurotettava työssään yhä pidemmälle luokkahuoneen ulkopuolelle. Tiina Soini, Janne Pietarinen ja Kirsi Pyhältö tarkastelevat arikkelissaan opettajan työssä jaksamista ja pedagogista hyvinvointia kasvatus- ja koulutustehtävän ristiaallokossa. Pedagoginen hyvinvointi perustuu eheyden ja merkityksellisyyden kokemukseen sekä kuulumisen ja osallisuuden tunteeseen. Yhä haastellisempien ongelmien kohtaaminen koulun arjessa edellyttää kokonaisvaltaista otetta vaativaan kasvatustyöhön sekä mahdollisuutta yhteisölliseen ongelmanratkaisuun. En usko, että aikuiskasvattajat eroavat työnsä haasteisuudessa juurikaan peruskoulun opettajista. 